\title{
PROXY CONTESTS AND THE GOVERNANCE OF PUBLICLY HELD CORPORATIONS*
}

\author{
Harry DeANGELO and Linda DeANGELO \\ University of Michigan, Ann Arbor, MI 48109, USA
}

Received January 1988, firal version received March 1989

\begin{abstract}
Analysis of 60 proxy contests for seats on the boards of exchange-lis 1 firms during 1478-1985 shows that three years after the contest less than one-fifth of the sample irms remain independent. publicly held corporations run by the same management team. Proxy contests are typically followed by managerial resignations, even when dissidents fail to obtain a majority of board seats, and are often followed by sale or liquidation of the firm. The average stockholder wealth gains associated with proxy contests are largely attributable to gains by companies in which dissident activity leads to sale or liquidation.
\end{abstract}

\section{Introduction}

The proxy contest is widely viewed as the ultimate vehicle enabling stockholders of publicly held corporations to discipline incumbent managers who fail to maximize firm value [Manne (1965), Alchian and Demsetz (1972)]. Despite its theoretical importance as a managerial disciplinary mechanism, however, we know little about whether or how proxy contests achieve this objective. For example, there is little svstematic evidence explaining why dissident stockholders wage proxy contests rather than seek control through other methods. Similarly, with the exception of DeAngelo (1983), there has been little analysis of the process through which dissidents convince voting stockholders that the incumbents are indeed inefficient managers. Finally, while it is known that dissidents usually do not obtain majority control through a proxy contest [Dodd and Warner (1983)], the effect of dissident activity on the eventual ownership and management of target firms remains an unexplored empirical issue.

\footnotetext{
*Helpful comments were received from Lisa Borstadt, James Brickley, Clifford Holderness, Wayne Marr, Ronald Masulis, Eric Noreen. Patricia O'Brien. Edward Rice, Roberta Romano, Katherine Schipper, Kenneth Scott, Dennis Sheehan. James Sington, Clifford Smith. Richard Smith, Joanne Turner, Jerold Warner, Michael Weisbach. J. Fred Weston, Jerold Zimmerman. Thomas Zwirlein, the referees, George Baker and John Pourd, and the editor, Michael Jensen. This study received financial support from the $\mathbf{J}$. Ira Harris Center lo: the Study of Corporate Finarce at the University of Michigan, the Arthur Young Foundation, and the Managerial Economics Research Center at the University of Rochester. We would like to thank Gita R zo and Douglas Skinner for their research assistance.
} 
This paper provides evidence on these and related issues. Our empirical analysis yields several broad generalizations about the conduct and consequences of proxy contests. First, dissident stockholders typically campaign for votes by painting a simple 'broad brush' picture of managerial inefficiency, using a variety of easy-to-convey criticisms such as poor operating profits or an allegedly inadequate dividend payout. Second, dissidents often possess industry, firm-specific, or takeover-related expertise that may help convince public stockholders of dissidents' ability to manage the firm or to effect beneficial changes in corporate policy. Third, resource limitations of the dissident group appear to encourage the choice of proxy contest as a takeover vehicle, since most dissident groups consist of individuals or private firms, with only one-fifth including participation by a publicly traded corporation.

Typically, whether or not the dissidents win the contested board election, members of the top management team lose their positions, either through the proxy contest itself or through other means shortly thereafter. Although the dissidents prevail in about one-third of our sample, another one-third of the firms experience resignations by top managerial personnel within three years of contest outcome, and most of these occur within one year. Moreover, roughly one-quarter of the sample firms are sold or liquidated shortly after the proxy contest. Taken together, these facts lead to the striking observation that less than one-fifth of sample firms remain independent, publicly neld corporations run by the same management team three years after the proxy contest. This evidence indicates that, once a proxy contest materializes, incumbent managers face a serious threat to their tenure.

Viewed collectively, our evidence supports the perspective that proxy contests serve as a catalyst through which public stockholders initiate a referendum on major corporate policy shifts. Ancillary evidence supporting this perspective includes our finding that the overall stockholder wealth gains associated with proxy contests are largely attributable to gains by sample companies in which dissident activity leads to sale or liquidation of the firm. We also find that stockholder wealth falls when it is announced publicly that incumbents have successfully warded off the dissidents, but that these losses occur primarily when incumbent managers use corporate resources to induce the dissidents to abandon their takeover attempt. These latter two findings suggest that acquisition-related benefits and costs are an important component of the stockholder wealth effects of proxy contests.

The paper is structured as follows. Section 2 describes our sampling procedure, and provides evidence on the incidence of proxy conitests and the public indications of dissident activity that iypically presede them. Section 3 analyzes the campaign issues and the evidence cited by dissident stockholders in favor of the proposed change in board composition. Section 4 presents evidence on dissident and target attributes, and identifies two potentially important factors that encourage the use of vote solicitation as a takcover method. Section 5 
reports the stockholder wealth consequences of dissident activity, and the relation between such activity and the subsequent sale or liquidation of the firm. Section 6 and the appendix document the relation between proxy contests and resignatiors by top management. Section 7 contains a brief summary.

\section{Sampling procedure and proxy conéest initiation}

Our sample consists of 60 proxy contests for board seats on 60 exchangelisted corporations during 1978-1985. Our source documents consist of the Weekly Bulletins of the New York Stock Exchange (NYSE) and American Stock Exchange (ASE) and the NYSE log of countersolicitations. These documents identify 70 proxy contests, but we exclude 10 contests for various reasons, largely because they are proxy solicifations by dissidents over specific corporate policy issues rather than attempts to obtain board representation. ${ }^{1}$ Of the final sample of 60 target firms, 40 were NYSE-listed and 20 were ASE-listed at the time of the contest, with an annual profile of:

\begin{tabular}{|c|c|c|}
\hline 1978: & 5 contests & 1982: \\
\hline 1979: & 8 contests & 1983: \\
\hline 1980: & 6 contests & 1984: \\
\hline 1981: & 10 contests & 1985: \\
\hline
\end{tabular}

Dodd and Warner (1983) report a similar incidence of proxy contests for board seats on exchange-listed firms during the earlier 1962-1977 period.

Over the last several decades, the incidence of proxy contests for board seats at exchange-listed firms has not differed markedly from the incidence of hostile tender bids. For example, over the period 1962-1983, the MERC and Austin data bases identify 171 listed firms whose managers faced tender bids that could be confirmed as hostile in financial press reports [Dann and DeAngelo (1988)]. Combining our 1978-1983 sample firms with these in Dodd and Warner (1983) for 1962-1977 yields a total of 141 proxy contests for board seats at listed firms over the same period. ${ }^{2}$ These facts run counter to the popular view that hostile tender bids greatly outnumber proxy contests.

\footnotetext{
'Specifically, we deleted one contest because we could find no mention of it in the Wall Street Journal Index, four contests because they were attempts to gain board seats for consumer advocate or employee groups, three contests bicause they were attempts to open-end a closed-end fund, one contest because it was a court-administered open election after CEO Robert Vesco fled the United States, and one contest because, contrary to the initial source document, the dissidents did not propose a slate of directors, but rather simply sought to delay the stockholder meeting.

${ }^{2}$ The 141 figure understates the incidence of proxy contests since it excludes contested elections over particular corporate issues such as the desirability of an antitakeover charter amendment. Issue contests are also empirically important since, e.g., 36\% of the proxy contests studied by Pound (1988) involved only a dispute over corporate policy and no attempt by dissidents to acquire board seats.
} 
This view (perhaps encouraged by greater press coverage of tender bids) seems to be weakening, given that managers of very large and newsworthy firms such as Gillette and Texaco have recently faced proxy contests.

Dissident stockholders explicitly sought control of 48 of the 60 firms in our sample. In 36 of these 48 contests, the dissidents sought to elect a majority of the target board, which would give them the ability to determine the identity of top management and to set major corporate policies. In the other 12 control contests, the dissidents' intent to obtain control was evidenced by their offer to purchase the target firm outright. ${ }^{3}$ These latter contests suggest a link between proxy contests and acquisition activity, and further evidence presented below clearly establishes the empirical importance of this relation. Finally, the dissidents' immediate goal in the last 12 contests was to obtain minority board representation, either to better monitor the policies of incumbent managers or to help managers identify and implement more profitable policies.

Publicly visible conflict between dissident stockholders and incumbent managers seldom begins with dissidents' announcement of their plans to wage a proxy contest. As table 1 documents, a contest announcement is the first visible sign of dissident activity in only 17 of our 60 sample contests. In 15 of the remaining 43 contests, dissidents first reveal an interest in boa:d seats, which they hope to obtain through negotiation with the incumbents or in some unspeciñed way. In other cases, dissidents initially request a stockholder list (four contests), state an interest in control without indicating they would necessarily wage a proxy contest to obtain it (seven contests), disclose an intent to influence managerial policies (three contests), or propose to acquire the firm (six contests). In eight contests, the first indication of dissident activity comes from the incumbents, who charge dissidents with an illegal attempt to obtain control or who simply reveal dissidents' existence/interest in the target firm.

Likewise, for 14 of the 17 cases in which contest announcement was the first public indication of dissident activity, we find evidence of prior private disagreements between the dissidents and incumbent management. In seven of these contests, the dissident leader is a former insider. In another seven, Wall Street Journal (WSJ) reports and proxy disclosures confirm that dissidents and incumbents had been in contact before the contest announcement. These observations suggest that proxy contests - unlike hostile tender bids in the widely held view - are not generally used as 'surprise raiding vehicles' to catch the management of a publicly traded corporation unawares. Rather, proxy

\footnotetext{
${ }^{3}$ The aissidents' immediate proxy fight objective was to obtain minority board representation in nine of the 12 contests in which they also offered to purchase the firm. The probable reason is that, in seven of the nine cases, the target elected directors to staggered terms so that a new majority stockholder could not immedia.ely elect a majority of the board. The dissidents apparently sought minority representation as a me ans of convincing the incumbents to seriously consider selling the firm.
} 
Table 1

Nature of first puoiic announctuent of uissivicat activity leading to a proxy contest for 60 piexy contests for board seats on New York and American stock exchange-listed firms (1978-1985).

\begin{tabular}{|c|c|c|}
\hline Nature of first disclosure & $\begin{array}{l}\text { Number } \\
\text { of contests }\end{array}$ & $\begin{array}{l}\text { Percent of } \\
\text { full sampie }\end{array}$ \\
\hline $\begin{array}{l}\text { Dissidents announce a proxy } \\
\text { contest for board seats }\end{array}$ & 17 & $28.3 \%$ \\
\hline $\begin{array}{l}\text { Initial public disclosure of dissident activity } \\
\text { precedes proxy contest announcement }\end{array}$ & 43 & $71.7 \%$ \\
\hline \multicolumn{3}{|l|}{ Breakdown of disclosure types so subsample } \\
\hline Dissidents reveal interest in board representation & 15 & $25.0 \%$ \\
\hline Dissidents reveal attempt to obtain stockholder List & 4 & $6.7 \%$ \\
\hline $\begin{array}{l}\text { Dissidents reveal interes: in control, but } \\
\text { do not specify particular takeover vehicle }\end{array}$ & 7 & $11.7 \%$ \\
\hline Dissidents reveal inient to influence corporate policies & 3 & $5.0 \%$ \\
\hline Dissidents propose to acquire target firm & 6 & $10.0 \%$ \\
\hline $\begin{array}{l}\text { Incumbents reveal opposition to } \\
\text { and/or existence of dissiderts }\end{array}$ & 8 & $13.3 \%$ \\
\hline
\end{tabular}

contests seem best viewed as a (radical) step in a continuing negotiation process in which the dissidents' inability to persuade incumbent management to implement their suggested policy shifts leads them to turn to outside stockholders for support.

\section{The nature and conduct of dissident campaigns}

To obtain the requisite support, dissidents must convince the other stockholders that a change in the board of directors is likely to increase the value of the firm. Dissidents typically wage these campaigns by publicizing multiple facts that collectively raise doubts about incumbents' performance, and that suggest a change in board composition is necessary to remedy the situation. Table 2 summarizes the managerial criticisms raised by the dissident stockholders of our 60 sample firms. We compiled this summary from the WSJ reports about each cortest and all contest-related proxy statements available from Disclosure. The precise phrasing varies across campaigns, and we have therefore used our judgment to categorize the criticisms. The dissidents in a given contest typically raise a subset of these criticisms, and the specific combination of complaints varies across campaigns.

Dissidents most frequently argue that the incumbents have done a poor job either of managing the firm's current operations or of setting overall investment policy. In 41 of the 60 sample contests (68.3\%), the dissidents slaim that 
Table 2

Dissidents' criticisms of incumbent managers in 60 proxy contests for board seats on New York and American stock exchange-listed firms $(1978-1985){ }^{a}$

\begin{tabular}{lcc}
\hline & $\begin{array}{c}\text { Number } \\
\text { of contests }\end{array}$ & $\begin{array}{c}\text { Percent } \\
\text { of sample }\end{array}$ \\
\hline Operating and investment policies & 41 & \\
Poor operating performance & 28 & $68.3 \%$ \\
Should consider sale of firm & 16 & 46.7 \\
Should consider asset mix change & & 26.7 \\
Financial policies and ownership structure & 17 & 28.3 \\
Unsatisfactory dividend policy & 17 & 28.3 \\
Low stock ownership by board & 5 & 8.3 \\
Excessive debt & & \\
Managerial integrity and general competence & 30 & 50.0 \\
Inappropriate takeover resistance & 21 & 35.0 \\
Unwarranted compensation/perquisites & 14 & 23.3 \\
Incompetent/unreliable management & & \\
\hline
\end{tabular}

${ }^{a}$ These criticisms are compiled from all (i) dissident proxy statements available from Disclosure and (ii) Wall Street Journal reports about sample contests. The phrasing of dissidents" criticisms varies from case to case and the categories presented here reflect our judgment of their primary concerns in each particular case. The categories are not mutually exclusive, i.e., each dissident group typically raised multiple criticisms of incumbent management.

incumbents' operating performance is unsatisfactory. They cite a variety of performance indicators to support this claim, including low or declining earnings, a recent string of accounting losses, a low return on equity, a low market-to-book ratio, and/or a decline in the firm's stock price. In criticisms of incumbents' operating performance, aissidents tend to emphasize accounting rather than stock price measures of performance, perhaps because dissident activity itself typically results in material stock price increases. [See DeAngelo (1988) for an analysis of the use of accounting and stock price information in proxy fights.]

In 28 sample contests, dissidents argue that managers should consider sale or liquidation of the firm. A typical argument is that these transactions would create greater value for stockholders than would continued operation as an independent, publicly held entity under the direction of incumbent management. In 16 sample contests, dissidents argue that managers should consider a less radical change in the firm's asset structure, e.g., a partial divestiture of corporate assets, initiation of an acquisition program, or changes in certain divisional operations or product lines. Overall, dissidents' suggestions for changes in investment policy range from concrete proposals to sell or liquidaie the firm and detailed plans to effect particular asset mix changes, to vague 
promises that the dissidents will investigate such possibilities, once elected to the board.

Dissidents also commonly claim that the firm's financial policies are inappropriate for its particular circumstances, and that these inferior olicies are both the result and cause of incumbents' poor operating performance. In 17 contests, dissidents criticize the firm's dividend policy, frequently citing dividend omissions or cuts as evidence that incumbents are not generating adequate returns for stockholders, or that the firm's financial situation is more precarious than managers admit. ${ }^{4}$ Also in 17 contests, dissidents claim that managers own too little stock in the target firm, a shortcoming they often blame for creating undesirable incentives that might help account for incumbents' substandard operating performance. In five contcsts, the dissidents claim incumbents have overleveraged the firm, thereby unadvisedly reducing its earninge and/or liniting the cash dividends available for stockholders.

Finally, dissidents often question incumbents' integrity by citing publicly visible managerial decisions that have overtones of self-dealing or conflicts of interest. In 30 contests, they challenge incumbent-initiated takeover defenses that allegedly decrease the likelihood that stockholders will receive a premium for their shares (and increase managerial control of the firm). In 21 contests, dissidents claim the incumbents have awarded themselves excessively generous compensation. In such cases, dissidents often contrast incumbents' 'generous' compensation with the allegedly inadequate earnings or dividends they have generated for stockholders. In 14 contests, dissidents claim incumbents are simply incompetent or unreliable, e.g., because they have not delivered on past promises or because their forecasts have proved repeatedly to be biased.

In sum, dissidents typically campaign for board seats by citing rnultiple performance measures that collectively paint a 'broad brush' picture of managerial inefficiency. ${ }^{5}$ This approach probably reflects their perception that voting stockholders will be reluciant to view one or a few 'poor realizations' as reliable evidence that incumbents are inferior managers. Dissidents uniformly avoid complex statistical analyses of the firm's earnings or stock price performance, but rather publicize simple, readily understood evidence of poor management. For example, they focus on particular outcomes that are obvi-

\footnotetext{
${ }^{4}$ Castanias and Johnson (1987) provide evidence that the dividend yields of firms whose managers were subsequently engaged in a proxy contest are lower than the dividend yields of (i) a random sample of publicly held firms and (ii) a sample of firms whose stockholders subsequently received a tender bid.

${ }^{5}$ There is an important difference hetween presenting evidence that portrays the incumbents as inefficient, and establishing that they are in fact inefficient in some Nirvana (zero information cost) sense. Theoretically, proxy contests can be expected to occur when there is truly significant doubt about the relative managerial abilities of incumbents and dissidents. If it were easy to identify superior manageinent talent, there would be little incentive for both sides to incur significant costs to persuade voting stockholders to elect their team.
} 
ously undesirable ex post, such as accounting losses or stock price declines (often from the all-time historical high). Dissidents sometimes quote articles in the financial press that poriray incumbents in an unflattering light. Overall, their canapaign strategies seem to refiect an ascessment that voters have limited incentives to invest in detailed evaluations of incumbents' competence.

\section{Dissident sand target attributes}

Proxy contests differ from other methods of corporate takeover in that voting stockholders must be convinced of dissidents' ability to identify and implement profitable policies. Although it may be difficult to forecast how dissidents would perform, the business background of the dissident leader serves as one indication of dissidents' ability to generate greater overall value for stockholders. Panel A of table 3 documents the expertise of dissident leaders according to information in proxy statements and Wall Street Journal articles. In 29 of the 60 cortests, the dissident leader has prior experience in the target's line of business. In ten of these 29 cases, the dissident leader was previously employed by the target firm or has served on its board. These facts suggest that expertise specific to the target's line of business is potentially useful in identifying poorly managed firms and/or in convincing voting stockholders that dissident board representation would substantially increase target firm value. ${ }^{\circ}$

Table 3 also contains a frequency count of other expertise possessed by dissident leaders which, in our judgment, might help convince voters to elect dissident directors. In 12 contests, the dissident leader has general experience in manufacturing (six contests) or real estate (six contests). Such expertise might help them better manage the target's resources, or convince voting stockholders of their abiitity to effect value-increasing changes in corporate policy. In 11 contests, dissident leaders have general capital market reputarions as corporate raiders, suggesting that more than pure managerial or technological expertise affects a party's willingness to wage a proxy contest. This fact also suggests that proxy fight participation is determined at least in part by dissidents' ability to force a sale of the firm or other material poinsy shifts.

The apparent importance of diss dents' takeover-related expertise raises the question why dissidents seek board seats through vote solicitation rather than the purchase of voting stock. At this point, it is simply not possible to identify

\footnotetext{
${ }^{6}$ This intergetation is reiniorced by the observation that other members of the dissiaent slate have company and industry cxpertise in nine and 23 cases, respectively. Thesc facts are consistent with Dodd and Warner's $(1983)$ finding that, in $42.7 \%$ of their sample contests, former insiders participate in the dissident gonp. See also Borstadt and Zwirlein (1987) for further aralysis of the roles played by former insiders versus outsiders in proxy contests.
} 
Table 3

Expertise and composition of the dissident group in 60 proxy contests for board seats on New York and American stock exchange-listed firms (1978-1985).

Number of contesis

(A) Expertise of dissident leader

Target company expertise

Target industry expertise

Alleged corporate raider ${ }^{\mathrm{a}}$

Manufacturing expertise

Real estate expertise

Other private investor

10

19

11

6

6

8

(B) Composition of dissident group

Dissident group includes no publicly traded firm $\quad 48$

$\begin{array}{ll}\text { Dissident group includes a publicly traded firm } & 12\end{array}$

Cases in which the target's market value exceeds that of publicly traded dissident firm ${ }^{b}$

Mean (median) ratio of target's markeî value to that of publicly traded dissident firm ${ }^{b}$

$2.05(1.37)$

\footnotetext{
${ }^{a}$ Parties that we so classified are the Belzberg brothers, Coniston Partners, Asher Edelman (two contests), Clyde Engle (two contests), Sir James Goldsmith, Carl Icahn (two contests), Leucadia National Corporation, and Harold Simmons.

'Each firm's market value is based on Moody's Manuals' report of the number of shares of common stock outstanding and the average of the high and low share prise for the calendar year prior to the contested board election.
}

all of the economically relevant factors that determine why vote solicitation is used as a takeover method. However, ancillary evidence for our sample reveals two attributes of situations in which proxy contests are employed by dissidents. Specificaly, proxy contests appear to be a more attractive takeover vehicle when (i) resource limitations make it difficult for the dissident group to purchase control and/or when (ii) takeover barriers impede the immediate purchase of control.

In the majority of contests ( 48 of 60 ), the dissiden group consists only of individuals (acting on their own behalf or on behalf of a private firm or partnership). It seems reasonable to conjecture that such individuals choose to wage a proxy contest rather than lever their personal portiolios to the extent necessary to purchase control of an exchange-listed corporation. In such cases, there nust also be some source of uniqueness between the particular wealthconstrained dissidents and the target firm. (Resource limitations cannot be the only important factor, since otherwise entry by wealth-constrained dissidents would simply serve to identify profitable takeover opportunities for less constrained bidders.) At present, the available evidence does not allow us to 
reliably identify the technological or informational factors responsible for uniqueness between particular target firms and takeover agents. ${ }^{7}$ This issue is clearly important for future empirical work.

For the remaining 12 contests in which the dissident group includes a publicly traded corporation, the target firm is typically considerably larger than the dissident firm. Panel B of table 3 reports that the mean ratio of target to dissident equity value is 2.05 , with a median of 1.37 (range 0.23 to 5.97). In eight of the 12 contests, the target firm's total equity value exceeds that of the dissident firm as of the year before the contested election. Targets of mergers and tender bids are, by contrast, usually much smaller than their bidder firms. ${ }^{8}$ The size disadvantage of most dissident firms also suggests that the choice of proxy contest as a takeover vehicie reflects the dissidents' limited resources.

The ownership structures of the $: 2$ publicly traded dissident firms provide further evidence that resource constraints affect the decision to wage a proxy contest. For 11 of these firms, proxy disclosures and financial press reports reveal a substantial consolidated share block (of at least $20 \%$ and often a majority) that is typically owned by parties who are aiso members of the dissident group. If these parties desire to maintain their vote ownership percentage, they should be correspondingly reluctant to expand the dissident firm's equity base to the extent necessary to purchase the target corporation. Accordingly, it seerns plausible that their choice of proxy contest as a takeover vehicle at least in part reflects a desire to avoid dilution of their ownership position in the dissident corporation.

Finally, our evidence indicates that dissiden: stockholders tend to wage proxy contests when regulatury barriers and target takeover defenses restrict other methods of control transfer. Eleven of the 12 target firms for which dissidents both waged a proxy fight and made an acquisition proposal exhibit such takeover obstacles. These barriers include corporate charter and by-law provisions which specify staggered board terms that would delay election of a board majority by a new majority stockholder, poison pill securities and agreements to complete 'friendly hands' stock placements that could make any large stake purchased by the dissidents less valuable, and regulatory consiraints on the target firm that would impede a merger unless the incumbent

\footnotetext{
${ }^{7}$ We note in passing the table 3 data. which indicate that many dissidents possess target-specific, industry-specific, and takeover-related expertise.

${ }^{8}$ Asquith. Bruner, and Mullins (1987) document a 0.40 mean ratiu of post-offer target equity value to bidder equity value for the merger proposals they study. Bradley, Desai, and Kim (1988) document a 0.31 median (and 0.95 mean) ratio of pre-offer target value to bidder value for the tende: bids in their sample. The median is more informative about the typical size relation, since the cross-sectional distribution exhibits considerable skewness due to $\mathrm{s}$ subset of very large tender bid targets.)
} 
board gave its approval. ${ }^{9}$ These eleven cases provide especially clear evidence that proxy contests sometimes complement other methods of acquiring control of a publicly held corporation.

These eleven cases also suggest that proxy contests sometimes enable dissident stockholders to force a stockholder referendum on prospective mergers or liquidations supported by the dissidents but opposed by incumbent managers. The view that proxy contests sometimes facilitate the sale of a target company is consistens with Pound's (1988) findings that (i) dissidents' chances of winning an election are greater if they have made a formal offer to purchase shares, contingent upon their election victory, and (ii) dissident stockholders sometimes wage proxy contests not for board representation, bi.tt rather to defeat managerial proposals to adopt antitakeover charter amendments.

This takeover-facilitating view of proxy contests is also consistent with the circumstances of some of the more publicized and hotly contested proxy fights that postdate our 1978-1985 sample period. Each of the three most dramatic contested elections of the 1988 proxy season - the battles for Texaco, Gillette, and Irving Bank - was a referendum forced by dissident stockholders over their proposals that management sell the target firm. Moreover, recent articles in the financial press cite the apparent increase in proxy contests during 1988 as a response to managers' implementation of stronger tender offer defenses such as poison pills, and to the adoption of tougher state takeover laws. In addition, many observers interpret these recent proxy contests as evidence of an evolution toward election campaigns that complement takeover bids and away from campaigns that emphasize replacement of management per se. ${ }^{10}$

\section{The wealth effects of dissident activity}

Our event-study analysis of stock price performance in part confirms the findings of Dodd and Warner (1983) in that dissident activity in sample firms typically generates gains for target stockholders. Our analysis also uncovers two interesting new empirical regularities about the stockholder wealth effects

\footnotetext{
'Some of these sample firms had more than one type of takeover barrier. The incidence of the various takeover deterrents is as follows: staggered board terms (nine firms), poison pill securities (two firms), 'friendly hands' stock placements announced in response to dissidet is' takeover attempts (two firms), and regulatory obstacles lizked to banking and public utility operations (two firms).

${ }^{10}$ The complementary relation between proxy contests and takeover bids is neither limited to 1988 , nor even to the last several years. In our sample of $1978-1985$ contests, $46.7 \%$ of the dissident groups propose a sale of the target firm as part of their election campaign. $50 \%$ cite inappropriate takeover resistance as a reason to replace incumbent management, and $28.3 \%$ are sold or liquidated within three years of contest outcome. In Dodd and Warner's (1983, fn. 20) sample of 1962-1977 contests. $15 \%$ of the firms are merged within three years of contest outcome.
} 
associated with dissident activity. First, incumbent managers' defensive actions play an important role in explaining the significant stockholder losses observed in contests in which incumbents successfully ward off the dissidents' challenge. Second, thes average wealth gains experienced by target stockholders over the entire period of disstutest activity are largely explained by gains to those target firms in which dissident activity laads to sale or liquidation.

We use the single-factor market model with equai-wishted index to assess each firm's stock price performance. For a given firm we estimate market model parameters using continuously compounded daily returns for the 200 trading days ending 100 days before initiation of dissident activity. These estimated parameters are used to calculate prediction errors (abnormal returns to target company stockholders) for various intervals during each firm's event period. We calculate $z$-statistics using the standardized prediction error approach detailed in Dodd (1980) and Patell (1976).

\subsection{Stockholder wealth effects: Full sample findings}

For our full sample of 60 firms, we find an average abnormal stockholder wealth increase of $4.85 \%(z=10.83)$ for the two-day period including the day before and the day of the first Wall Street Journal report of dissident activity, and of $18.76 \%(z=9.44)$ when measured over the 40 trading days prior to and including the first public report. The announcement of a proxy contest is associated with an average two-day abnormal return of $3.82 \%(z=4.85)$ for the 17 contests for which the contest announcement represents the first sign of dissident activity, and of $2.94 \%(z=4.74)$ for the 43 cortests with prior public indication of dissident activity. Over the full interval from 40 days prior to initiation through contest outcome, the average abnormal stockholder wealth increase is $6.02 \%(z=4.32)$. For this interval, the market-adjusted returns approach [see Brown and Warner (1985)] reveals positive, but only marginally significant stock returns (mean $=2.99 \%$, median $=2.70 \%, z=1.87$ ).

We find negative, but insignificant stock returns for (i) the period following the initiation of dissident activity through the contest outcome $(-12.47 \%$, $z=-0.77)$ and (ii) the period following contest announcement through outcome $(-6.32 \%, z=-1.14)$. These returns become significantly negative under the market-adjuster returns approach, consistent with the earlier findings of Dodd and Warner (1983). We conjecture that these negative returns reflect the market's imperfect ability to distinguish sample firms ex ante from other firms that are more likely to be acquired at a premium. Also, since firms experiencing a proxy challenge tend to exhibit poor pre-contest financial performance [DeAngelo (1988)], post-contest announcement returns may reflect the arrival of (previously uncapitalized) new information about sample firms' poor financial health. If such information effects are important, our event-study findings will underestimate the overall wealth impact of dissident activity. 
Tablc 4

Stockholder wealth effects (prediction errors, $p e$ ) at initiation of dissident activity and proxy contest outcome for 60 proxy contests for board seats on New York and American stock exchange-listed firms (1978-1985).

\begin{tabular}{lccc}
\hline & \multicolumn{3}{c}{$\begin{array}{c}\text { Mean, median, z-statistic, } \\
\text { and fraction of positive } p c \text { 's for }\end{array}$} \\
\cline { 2 - 4 } $\begin{array}{c}\text { Sample category } \\
\text { (number of firms) }\end{array}$ & $\begin{array}{c}2 \text { days at } \\
\text { initiation }\end{array}$ & $\begin{array}{c}\text { at contest } \\
\text { outcome }^{\mathrm{a}}\end{array}$ & $\begin{array}{c}40 \text { days before } \\
\text { initiation through } \\
\text { contest outcome }\end{array}$ \\
\hline (A) Full sample & $4.85 \%$ & $-1.1 \% \%$ & $6.02 \%$ \\
$(n=60)$ & 2.89 & -0.43 & 6.62 \\
& 10.83 & -2.71 & 4.32 \\
& $(0.78)$ & $(0.42)$ & $(0.59)$ \\
\hline
\end{tabular}

(B) Sample partitioned by contest outcome

Dissidents obtain target board control $(n=21)$

Dissidents obtain some seats but not a majority of board $(n=16)$

Incumbents successfully deflect dissidents' takeover attempt $(n=23)$

$\begin{array}{ccc}6.51 \% & 2.60 \% & 9.47 \% \\ 5.73 & 1.43 & -3.47 \\ 8.63 & 2.90 & 1.44 \\ (0.90) & (0.62) & (0.48) \\ 4.01 & -0.24 & 30.12 \\ 1.95 & 0.14 & 14.44 \\ -8 & 0.34 & 4.77 \\ . .51) & (0.50) & (0.69) \\ 3.31 & -5.45 & -14.80 \\ 2.31 & -2.63 & 8.33 \\ 5.18 & -7.56 & 1.59 \\ (0.65) & (0.18) & (0.64)\end{array}$

${ }^{a}$ Measurement interval includes the day before and the day of the first public report of the event in the Wall Street Journal.

\subsection{Stockholder wealth effects by contest outcome}

Table 4 reports the average stockholder wealth impact at initiation, outcome, and over the entire period of dissident activity for our sample partitioned by the nominal outcome of the dissidents' challenge to incumbent management. By 'nominal' outcome, we mean the outcome of the proxy contest itself. The evidence reported below indicates that many sample firms experience major corporate policy shifts that can be linked directly to dissident activity. A broader view is that these policy shifts represent the economically relevant outcome of that activity.

The first outcome category in table 4 contains the 21 contests in which, according to Wall Street Journal reports, the dissidents obtain control of the target, either by acquiring a majority of board seats (18 contests) or by obtaining incumbents' explicit agreement to sell the firm to the dissidents (three contests). The second outcome category contains the 16 contests in which the dissidents obtain some board seats, but not enough to constitute a 
majority. For these 16 firms, $W S J$ reports do not reveal any explicit agreement to sell the firm to the dissidents, although we shall see that many of these firms were subsequently sold as a result of the dissidents' efforts. The third outcome category contains the 23 contests in which incumbents defeat the dissidents' challenge.

The data in table 4 reveal several interesting facts about the wealth consequences of dissident activity. First, regardless of the immediate outcome of the proxy contest, stockholder wealth increases materially - and by roughly the same amount - at the initiation of dissident activity. Although for brevity the data are not included in the table, the same inference applies when we measure abnormal stock returns from 40 days prior to initiation through initiation itself. ${ }^{11}$ One plausible explanation for this finding (explored further below) is that an external challenge to managerial policies increases the likelihood that corporate resources will be reallocated to higher-valued uses.

Table 4 also indicates that stockholders experience average wealth losses of $5.45 \%(z=-7.56)$ in the two days surrounding contest outcome for the 23 contests in which incumbents defeat the dissidents' challenge. This finding appears to indicate that stockholders are systematically harming themselves by mistakenly choosing to retain the inferior management team. However, closer inspection reveals that this in/erence is unwarranted since, in most of these 23 contests, stockholders play no direct role in the resolution of hostilities. Specifically, in only seven of these contests does a stockholder vote actually determine the outcome. For these seven contests, the average return at announcement of contest outcome is an insignificant $-1.73 \%(z=-1.51)$.

The outcomes of the remaining 16 contests are not determined by stockholder vote, but rather are ef ctively ended by incumbent managers' defensive actions. Specifically, 11 outcomes are settled by negotiations in which incumbents use corporate resources to induce the dissidents to abandon their takeover attempt. Another tiree outcomes are effectively determined when the dissidents withdraw because the courts uphold the validity of dsfensive restructurings announced by the incumbents. In the remaining two cases, the dissidents drop their takeover attempt because the incumbents agree to an acquisition by another party. For the 16 contests in which incumbents' defensive actions determine the outcome, the average stockholder return at outcome announcement is a significant $-7.19 \%(z=-8.13)$. These circumstances suggest that the stock price decline at defeat of dissidents' challenge should not be attributed to voting stockholders' naiveté in distinguishing the superior management team.

\footnotetext{
${ }^{11}$ For firms in which dissidents obtain control, the mean return from 40 days prior through initiation of dissident activity is $17.68 \%(z=4.46)$. For firms in which dissidents win some seats, but not a majority, the corresponding return is $16.47 \%(z=4.44)$, and it is $21.35 \%(z=7.28)$ for firms in which incumbents successfully deflect the dissidents.
} 


\subsection{Relation to acquisition activity}

Another interesting empirical finding reported in table 4 is the wide variation in stockholder returns (by nominal contest outcome) over the full period of dissident activity. On average, we observe large overall wealth gains only for the 16 contests in which dissidents obtain a minority of the directorships. For the other outcome categories, average stockholder returns are not significantly different from zero; moreover, the mean and median return are of opposite sign. ${ }^{12}$ The market-adjusted returns approach also indicates that stockholders experience significantly positive wealth effects only for the subsample in which dissidents obtain board representation, but not a majority of the directorships. ${ }^{13}$

It is puzzling that a compromise outcome in which both dissidents and incumbent managers obtain board representation generates especially large overall returns for stockholders. On the surface, such outcomes would seem to engender additional dissipation of resources in continued disagreements over tne appropriate corporate policies. As table 4 reports, however, stockholders experience significant overall returns of $30.12 \%$ (median $=14.44 \%$ ) in contests in which dissidents obtain a minority of directors. One possible explanation is that dissident bcaid representation leads to improved monitoring of managerial decisions, hence to the implementation of higher-valued corporate policies. But given the size of these wealth gains, one is naturally curious about the types of policy shifts that might be generated through dissidents' minority board representation and/or through their public challenge of incumberit management.

The data in table 5 suggest there is an empirically important relation between dissident challenges and the decision to scll the target firm. We find that $17(28.3 \%)$ of our full sample of 60 firms are sold ( $15 \mathrm{firms})$ or liquidated (two firms), either during the proxy campaign or shortly thereafter. In 14 of these 17 cases, the sale or liquidation is announced within one year of contest outcome. All of these transactions and the additional company sale announced the following year (a total of 15 transactions) are clearly cornected to dissident stockholders' proxy challenges. ${ }^{14}$ Specifically, in six case the dissi-

\footnotetext{
${ }^{12}$ The differences between mean and median reflect the modest size of the subsaraples and the long intervals over which stock returns are often cumulated. Accordingly, market model parameter estimation errors can generate outlier observations (via repeated cumulation) that unduly influence the mean return. This possibility is of second-order concern for the inferences drawn here since, regardless of whether one relies on means or medians (or uses the markei-adjusted returns method whose results are reported in footnote 13), there is no indication that stockholders in the first and third outcome categories typically experience significant wealth gains.

${ }^{13}$ For the three outcome categories, the mean, median, and $z$-statistic under the market-adjusted returns method are (i) $9.70 \%, 11.64 \%, z=1.45$; (ii) $12.67 \%, 17.89 \%, z=2.33$; (iii) $-10.45 \%$, $-3.18 \%, z=-0.34$.

${ }^{14}$ All 15 proposed ti ansactions were eventually completed. Two additional sales (also eventually completed) were proposed within three years of contest outcome, but we find no apparent link between these latter two transactions and the dissidents' proxy challenges.
} 
Table 5

Incidence and timing of company sales/liquidations for 60 proxy contests for board seats on New York and American stock exchange-listed firms (1978-1985). ${ }^{\mathrm{a}}$

\begin{tabular}{|c|c|c|c|c|c|}
\hline \multirow[b]{2}{*}{$\begin{array}{l}\text { Outcome } \\
\text { subsample }\end{array}$} & \multirow[b]{2}{*}{$\begin{array}{l}\text { Number } \\
\text { of firms }\end{array}$} & \multicolumn{4}{|c|}{ Announcement of sale/liquidation } \\
\hline & & $\begin{array}{l}\text { Between } \\
\text { initiation } \\
\text { and contest } \\
\text { outcome }\end{array}$ & $\begin{array}{c}\text { First } \\
\text { year } \\
\text { after } \\
\text { outcome }\end{array}$ & $\begin{array}{l}\text { Second } \\
\text { year } \\
\text { after } \\
\text { outcome }\end{array}$ & $\begin{array}{c}\text { Third } \\
\text { year } \\
\text { after } \\
\text { outcome }\end{array}$ \\
\hline $\begin{array}{l}\text { Dissidents gain board } \\
\text { control via proxy contcst }\end{array}$ & 4 & 3 & 1 & 0 & 0 \\
\hline $\begin{array}{l}\text { Dissidents obtain some } \\
\text { seats, but not control }\end{array}$ & $8^{b}$ & 1 & 5 & 1 & $1^{b}$ \\
\hline $\begin{array}{l}\text { Dissidents obtain no } \\
\text { board seats }\end{array}$ & $5^{b}$ & 2 & 2 & 0 & $1^{b}$ \\
\hline Total & 17 & 6 & 8 & 1 & 2 \\
\hline
\end{tabular}

\footnotetext{
${ }^{a}$ These transaction timing dates refer to the initial announcement of an eventually completed plan or agreement to sell or liquidate the target firm.

'This category contains one firm whose sale or liquidation is not clearly linked to the dissidents' proxy challenge.
}

dents themselves acquire the firm, in three cases acquisition by a third party effectively ends the contest, in five cases the dissidents' campaign places major emphasis on selling the firm, and in one case the firn is acquired by a party with which managers had privately placed shares to defeat the dissidents.

A closer look at the 15 firms whose sale or liquidation can be clearly linked to the efforts of dissident stuckholders reveals that in seven cases the dissidents had obtained a minority of the board seats (see the second outcome category of table 4). These seven firms represent $43.8 \%$ of the 16 companies in which dissidents obtain a board minority. We find a much smaller fraction of target companies whose sale or liquidation is linked to the proxy contest in the other two outcome categories. Specincally, these firms comprise four (19.0\%) of the 21 cases in which dissidents obtain target control, and four (17.4\%) of the 23 cases in which the dissidents are defeated by incumbents. These findings suggest that minority representation per se can help dissident stockholders force the sale or liquidation of the target firm when it is valuable to do so, and when incumbents are reluctant to take the necessary steps.

Perhaps more importa ttly, these facts support a general empirical linkage between dissident : alvity and the eventual sale of the target firm. In fact, the data in table 6 reveal that the overall wealth gains associated with dissident activity (documented above) are largely driven by gains to those firms that were subsequently sold or liquidated as a result of the dissidents' efforts. For the 15 firms whose sale or liquidation is clearly linked to dissidents' efforts, the average wealth gain over the full period of dissident activity is a significant $15.16 \%(z=4.21)$. For the remaining sample firms, the corresponding mean 
Table 6

Selected stockholder wealth effects (prediction errors, pe) for 60 proxy contests for board seats on New York and American stock exchange-listed firms (1978-1985), partitioned by whether sale of firm is linked to dissident activity.

\begin{tabular}{lcc}
\hline & \multicolumn{2}{c}{$\begin{array}{c}\text { Mean, median, } z \text {-statistic, } \\
\text { and fraction of positive } p e \text { 's for }\end{array}$} \\
\cline { 2 - 3 } $\begin{array}{c}\text { Sample category } \\
\text { (number of firms) }\end{array}$ & $\begin{array}{c}40 \text { days before } \\
\text { contest initiation }\end{array}$ & $\begin{array}{c}40 \text { days before } \\
\text { initiation through } \\
\text { contest outcome }\end{array}$ \\
\hline (A) $\quad$ Full sample & $18.76 \%$ & $6.02 \%$ \\
$(n=60)$ & 16.58 & 6.62 \\
& 9.44 & 4.32 \\
& $(0.78)$ & $(0.59)$ \\
\hline
\end{tabular}

(B) Sample partitioned by whether sale of firm is linked to dissident activity

Sale of target firm is linked to dissident activity ${ }^{\mathrm{a}}$ $(n=15)$

$\begin{array}{cc}22.36 \% & 15.16 \% \\ 20.20 & 21.96 \\ 5.90 & 4.21 \\ (0.93) & (0.80) \\ & \\ 17.56 & 2.90 \\ 14.04 & 518 \\ 749 & 2.54 \\ (0.73) & (0.52)\end{array}$

No evidence that any sale of target firm is linked to dissident activity $(n=45)$

$(0.73)$

${ }^{a}$ For these 15 cases, financial press reports clearly link the sale or liquidation of the target firm to dissident activity. In six of these cases the dissidents themselves acquire the firm, in three cases acquisition by a third party effectively ends the proxy contest, in five cases the dissidents' campaign placed major emphasis on selling the firm, and in one case the firm is acquired by a party with which managers had privately placed shares in an attempt to defeat the dissidents.

return is a considerably smaller $2.90 \%(z=2.54)$. Similarly, the $21.96 \%$ median overall stockholder return in the 15 firms with a dissident-linked sale or liquidation is considerably greater than the $5.18 \%$ median overall return in the remaining sample îrms. ${ }^{15}$

Table 6 also reveals that stockholders of firms in both subsamples experience significant wealth gains (on the order of $20 \%$ ) around the initiation of dissident activity. A plausible explanation is that the initial run-up in target value is attributable to the market's perception that the dissidents' challenge increases the likelihood that firms in both subsamples will be sold at a premium. By this view, the market is not able to separate ex ante the subset of firms that will subsequently be sold or liquidated from the subset that will not be. For the latter firms, the lower returns over the period from initiation

\footnotetext{
${ }^{15}$ The same picture obrains when we calculate cumulative returns based on the market-adjusted returns method. For the 15 firms whose sale or liquidation is linked to dissident activity, the mean return is $23.39 \%$, the median is $26.50 \%$, and the $z$-statistic is 3.60 . For the remaining 45 firms, the corresponding figures are $-3.96 \%,-2.91 \%$, and $z=0.06$.
} 
through outcome reflect a growing awareness, as the nature of the dissidents' challenge becomes clearer (and perhaps evolves in response to incumbents' actions), that the target firm will not be acquired.

\section{Managerial resignations and dissident activity}

Dodd and Warner (1983) report that dissidents who wage proxy contests infrequently win majority control of the board. They find that dissidents successfully obtain a board majority only $20-25 \%$ of the time, which is quite close to the finding (reported above) that dissidents win a board majority in approximately one-third of our sample of proxy contests. These relatively low nominal success rates seem to suggest that the advent of a proxy contest represents an ineffective threat to top management because these contests typically do not cost incumbents their positions.

A closer look at the impact of proxy contests - viewed broadiy to include managerial resignations and company sales linked directly to dissidents efforts - seriously challenges the view that incumbents have little to fear from a proxy contest. First, as discussed above, 17 of our 60 sample firms are sold or liquidated during the proxy contest or shortly thereafter, and 15 of these transactions are clearly linked to the dissidents' efforts. Second, as we next document, nore than haif the tirms in which dissidents did not obtain board control experience resignations in top management [defined as a chicf executive officer (CEO), chairman, and/or president], either during or shor tly after the contest. Detailed case studies of these resignations (presented in the appendix and summarized here) reveal that at least three-quarters are directly related to the dissidents" attempts to replace incumbent managers.

To assess the frequency of managerial resignations for the 39 firms in which the dissidents did not obtain board control through the proxy contest, we inspect the Wall Street Journal for evidence of changes in CEO, chairman, and/or president around the time of the proxy contest. This search reveals resignations by individuals holding these titles in 20 of the 39 firms (51.3\%), either during the proxy contest itself or within the three years of the contest outcome. In almost all (17 of 20 ) cases, the individual who resigned held the CEO position. All told, we observe resignations by 23 individ, als of 38 manageria! positions - 17 CEO positions, 11 board chairmanships, and 10 presidencies - in these 20 firms. The median age at resignation is 59 , and the only two indivicuals who resigned close to the 'normal' retirement age of 65 had personally been the subject of scathing attacis by the dissidents (see the case studies in the appendix for Condec and Kennecott Corp.). ${ }^{16}$

Some indication that the managerial resignations we observe are linked to the dissidents' proxy challenge can be found in panel $\mathrm{A}$ of table 7 , which

\footnotetext{
${ }^{16}$ The age distribution at resignation is as follows: less than 50 years old, three individuals; between 50 and 59, nine individuals; between 60 and 63, six individuals: 65 or 66, two individuals: 69 or older, three individuals.
} 
Table 7

Resignations by CEOs, presidents and/or board chairmen for the subsample of 39 exchange-listed firms in which dissidents did not obtain board control in a proxy contest (1978-1985).

\begin{tabular}{|c|c|c|c|c|c|}
\hline & $\begin{array}{c}\text { All } \\
\text { cases }\end{array}$ & $\begin{array}{l}\text { Between } \\
\text { initiation } \\
\text { and contest } \\
\text { outcome }\end{array}$ & $\begin{array}{l}\text { First } \\
\text { year } \\
\text { after } \\
\text { outcome }\end{array}$ & $\begin{array}{l}\text { Second } \\
\text { year } \\
\text { after } \\
\text { outcome }\end{array}$ & $\begin{array}{l}\text { Third } \\
\text { year } \\
\text { after } \\
\text { outcome }\end{array}$ \\
\hline Number & 20 & 2 & 13 & 2 & 3 \\
\hline $\begin{array}{l}\text { Percent of } \\
\text { subsample }\end{array}$ & $51.3 \%$ & $5.1 \%$ & $33.3 \%$ & $5.1 \%$ & $7.7 \%$ \\
\hline \multicolumn{6}{|c|}{ (B) Nature of resignation } \\
\hline & & & \multicolumn{2}{|c|}{$\begin{array}{l}\text { Number } \\
\text { of firms }\end{array}$} & $\begin{array}{l}\text { Percent of } \\
\text { subsample }\end{array}$ \\
\hline \multicolumn{3}{|c|}{$\begin{array}{l}\text { Resignation with replacement by } \\
\text { dissident or buyer in 'friendly } \\
\text { hands' stock placement }\end{array}$} & \multicolumn{2}{|c|}{6} & $15.4 \%$ \\
\hline \multicolumn{3}{|c|}{$\begin{array}{l}\text { Resignation before contest } \\
\text { outcome was resolved }\end{array}$} & \multicolumn{2}{|c|}{2} & 5.1 \\
\hline \multicolumn{3}{|c|}{$\begin{array}{l}\text { Resignation amid continued signs } \\
\text { of conflict with dissidents who } \\
\text { now have board representation }\end{array}$} & \multicolumn{2}{|c|}{3} & 7.7 \\
\hline \multicolumn{3}{|c|}{$\begin{array}{l}\text { Resignation with other } \\
\text { signs of dissident involvement }\end{array}$} & \multicolumn{2}{|c|}{4} & 10.3 \\
\hline \multicolumn{3}{|c|}{$\begin{array}{l}\text { All other resignations (all at } \\
\text { other than normal retirement age) }\end{array}$} & \multicolumn{2}{|c|}{5} & 12.8 \\
\hline
\end{tabular}

reports the timing of these resignations in relation to the outcome of the proxy contest. These data reveal that the resignations are bunched close in time to the election campaign, as one might expect if the dissidents' efforts influenced the management change. Fifteen of the 20 resignations occur either during the contest itself or within one year of the outcome. Viewed in relative terms, a full $38 \%$ (15 of 39 ) of the sample firms in which dissidents fail to obtain a majority of the directorships through the contested board election experience resignations by top manacgerial personrel within one year of the contest outcome.

This $38 \%$ resignation ra e is mach greater than the rates typically found in empirical studies of top management changes. ${ }^{17}$ For example, Warner, Watts.

\footnotetext{
${ }^{17}$ It i . difficult to specify on a priori ground the appropriate interval for measuring man igerial turnover related to dissident challenges. Here we emphasize the resign 'tion rate measured through one year after the contest outcome, since proximity to the contest seems a good indiration that the dissidents' efforts played a significant role. We also study each managerial resignation for signs of dissident involvement - see the case study discussion below.
} 
and Wruck (1988) document an average annualized rate of $11.5 \%$ for arrivals or departures by top management (including retirements from the CEO, chairman, or president positions) reported in the Wall Street Journal. They find considerably lower management change rates (ranging from 1.4\% to 6.0\%, depending on company stock price performance) for changes they classify as forced by the board of directors. Weisbach (1988) documents an average rate for CEO departures (excluding retirements) of $4.8 \%$ for NYSE-listed firms, which is about half the retirement-inclusive departure rate for his sample. Coughlan and Schmidt (1985) find an average CEO department rate of $12.7 \%$ (8.0\% for CEOs younger than age 63) for firms listed in the Forbes compensation survey.

Thus, while the details of our sampling algorithm differ from those used in prior studies of top management changes, it seems reasonable to infer that the incidence of resignations dccumented here is not plausibly attributable to 'normal' managerial turnover. Rather, the resignation frequency for the current sample appears more in line with the management change rates previously documented for other significant - and, for top management, also potentially traumatic - corporate events. The $38 \%$ resignation rate discussed above is roughly the same order of magnitude as the 33\% management change rate reported by Gilson (1988) for firms experiencing financial distress, the 27\% change rate reported by Klein and Rosenfeld (1988) for firms whose managers pay greenmail to deflect a possible takeover, and the $25 \%$ charge rate reported by Walsh (1988) for firms that are acquired by another public corporation. ${ }^{18}$

Ideally, one would like to know whether the dissidents' proxy challenge significantly influenced the managerial resignations we document here. As Warner, Watts, and Wruck (1988) and Weisbach (1988) clearly establish, however, public sources rarely disclose the 'true' reasons for a management change (probably because both the company and the executive involved suppress information they view as potentiallv embarrassing). Nevertheless, by piecing together information from financial press reports about the firm-specific circumstances surrounding each resignation in our sample, we are able to obtain qualitative evidence on the role played by the dissidents' challenge. This evidence is contained in the appendix, which provides detailed case studies of the managerial resignations that occur within three years of contest outcome at 20 sample firms in which dissidents fail to obtain a board majority through the contested board election.

\footnotetext{
${ }^{18}$ Although it does not alter the point made in the text, these studies use somewhat different management change definitions from ours. Gilson's data refer to the per-firm rate of arrivals or departures by the CEO, chairman, or president. Klein and Rosenfeld's data refer to the per-firm departure rate by the CEO, chairman, or president. Walsh's data refer to the departure rate per-position for members of 'top management' and are based or. a survey of successfully acquired merger targets (with a survey response rate of $39 \%$ ).
} 
A reading of these case studies uncovers evidence that, in 15 (75\%) of the 20 firms, the managerial resignations are plausibly linked to the dissidents' efforts to unseat incumbent manage nent. The nature and strength of this evidence varies from case to case and is summarized in panel B of table 7. Strong evidence of the importance of the dissidents' challenge is the replacement of the resigning manager in six of the 15 firms by a dissident or by a blockholder to whom the incumbents had sold shares in a 'friendly hands' placement to diminish the dissidents' voting power. The identity of these managerial replacements leaves little doubt that the dissidents' efforts played a key role in effecting these resignations. Moreover, the case studies for these firms (American Bakeries, Condec, Deltona, FGI Investors, LLC Corporation, and Pantry Pride) provide confirmatory evidence of conflicts between the farticular manager who resigned and the dissidents or the new blockholder (whose alliance with incumbent management evidently ended shortly after the contest).

In another five cases, the managerial resignation occurs during hostilities between the incumbents and dissidents, with three resignations taking place after the contest had apparently ended, but amid visible signs of renewed conflict with dissidents who had obtained board representation. (See the case studies for Canal Randolph, Chicago Rivet, Citadel Holding, Kennecott, and Management Assistance.) The fact that these resignations came during visible - and, as the case studies indicate, often quite heated - conflicts between the dissident and incumbent groups provides corroborative evidence of the dissidents' role in effecting these management changes. Moreover, in four of the five cases, financial press reports indicate that the particular individual who resigned had experienced direct personal conflicts with the dissidents.

In another four cases, other deiails reported by the Wall Street Journal suggest that dissident activity played a role in the managerial resignation, but the evidence is not as strong as for the eleven cases just discussed. In three of these four cases, the resignation occurs after the dissidents had obtained board representation and while the firm was experiencing significant financial difficulties as evidenced, for example, by large reported losses (Cook United, H. H. Robertson, and Saxon). In the remaining case (Pullman), the resignation came within six months of the dissidents' failure to obtain any seats, but followed a campaign that emphasized the alleged incompetence of the individual who ultimately resigned. During this campaign, the Wall Street Journal reported that the dissidents 'are betting that even if they can't unseat Mr. Casey (the firm's CEO) by a proxy contest, the questions they are raising will stir up enough adverse publicity to force him out of office'.

The final five cases, by our judgment of $W S J$ reports, do not reveal a direct connection between the managerial resignation and the dissidents' proxy challenge (see the appendix entries for Chock Full O'Nuts, Louisiana Land \& Exploration, New Jersey Resources, Texas International, and Tosco). All five resignations occur at other than 'normal' retirement age, suggesting that some 
Table 8

Cumulative survival rate for incumbent management for 60 proxy contests for board seats on New York and American stock exchange-listed firms (1978-1985). ${ }^{a}$

\begin{tabular}{lcc}
\hline & \multicolumn{2}{c}{$\begin{array}{c}\text { Incidence of independent, publicly traded } \\
\text { target firms with top management intant } \\
\text { as of specified date }\end{array}$} \\
\cline { 2 - 3 } Evaluation date & \multicolumn{2}{c}{$\begin{array}{c}\text { Number } \\
\text { of firms }\end{array}$} \\
\hline As of ituitiation of dissident activity & 60 & $\begin{array}{c}\text { Percent } \\
\text { of sample }\end{array}$ \\
As of outcome of contest & 34 & $100.0 \%$ \\
As of one year after outcome & 17 & 56.7 \\
As of two years after outcome & 14 & 28.3 \\
As of three years after outcome & 11 & 18.3 \\
\hline
\end{tabular}

\footnotetext{
${ }^{a} W_{\varepsilon}$ treat the incumbent management team as surviving intact as of a given date if (i) the dissidents fail to obtain board control through the proxy contesi (per table 4), (ii) there are no resignations by CEOs, presidents, or board chairmen (per table 7), and (iii) the corporation is not scild or liquidated (per table 5). Tlia cumulative survival figures reported here exceed those implied by the sum of the attrition figures documented in tables 4,5 , and 7 because some firms appear in more than one of these tables.
}

of these departures may be linked to the dissidents' efforts. Moreover, such linkage seems quite possible for the Louisiana Land and Tosco cases, since a reading of the appendix shows that our classification of the dissidents' role as unimportant in these resignations involved especially tough judgment calls, which another observer might reasonably reverse.

In sum, the case studies detailed in the appendix yield the overali impression that, even when dissident stockholders fail to obtain a board majority through a proxy contest, their efforts nonetheless frequently play a significant role in effecting a change in corporate top management. Of course, we have insufficient evidence to infer that the dissiden 's' efforts were the single critical factor in the managerial resignations we observe. For example, the possibility remains that other disciplinary forces (e.g., monitoring by the incumbent board) would have eventually led to the same managerial resignations. All we can reliably say is that the circumstances surrounding most of these resignations suggest that the dissidents' efforts were important in effecting the management changes.

Table 8 documents the cumulative survival rate for incumbent top managers of our sample firms for the period beginning with initiation of dissident activity and ending three years after contest outcome. The incumbent management team is treated as surviving intact as of a given date if (i) the dissidents fail to obtain board control through the proxy contest (per table 4), (ii) there are no top management resignations (per table 7), and (iii) the firm is not sold or liquidated (per table 5). The striking empirical ract is that, in less than one-fifth of our sample, the same incumbent :anagement team remains in 
control of the (still publicly held) target firm three years after the contest outcome. Moreover, as discussed above, the vast majority of this managerial attrition is directly connected to the ciissidents' efforts.

The evidence accordingly suggests that, once a dissident challenge iraterializes, there is a considerably greater threat to incumbeni managers than is implied simply by the frequency with which dissidents obtain a board majority through stockholder vote. Although this evidence indicates that dissident activity represents a more effective threat to incumbent management than is commonly thought, it does not imply that the 'right' (i.e., economically efficient) number of proxy contests necessarily takes place. [See Pound (1988) for a discussion of factors that potentially affect the economic afficiency of stockholder voting as a mechanism for disciplining managers.]

Another important caveat is that our evidence does not imply wat onily poor manage $_{2}$, are challenged in - or removed through - dissidents' proxy solicitations. On the contrary, because resources are expended in proxy solicitations when there are material information costs for outsiders to identify the superior management team, one would expect that some dissident cinailenges actually focus on (and ultimately remove) incumbent managers who are in fact better at operating the firm. Symmetrically, material information costs will sometimes enable relatively inefficient incumbents to survive a dissident challenge. In sum, given that proxy contests inherently arise because of positive information costs of evaluating alternative management teams, there is no reason to expect that they will always give control to the superior group.

\section{Summary and conclusions}

This paper provides an empirical analysis of the conduct and consequences of 60 proxy contests for board representation on New York and American Stock Exchange-listed corporations during 1978-1985. We find that dissident stockholders typically campaign for the public stockholder vote by painting a simple 'broad hrush' picture of managerial inefficiency, using a variety of easy-to-convey criticisms of managerial performance. Dissidents often possess industry, firm-specific, or takeover-related expertise that public stockholders might view as favorable indications of their ability to manage the firm or to effect beneficial changes in corperate policy. Resource limitations appear to affect the dissidents' cheice of a proxy contest as a takeover vehicle, since most dissident groups consist of individuals or private firms, with only one-fifth including participation by a publicly traded corporation. Moreover, in these latter cases, the dissident firm is on average half the size of the target firm.

Consistent with Dodd and Warner (1983), we find that dissident activity is associated with ov $\Leftrightarrow$ rall stockholder wealth gains, and that stockholders typically experience losses at announcement that the dissidents have failed to obtain board representation. We also find, hovever, that the significant overall 
wealth gains associated with proxy contests are largely attributable to gains by those sample firms in which dissident activity leads to sale or liquidation of the corporation. Moreover, the wealth losses at the xuicomes of unsuccessful proxy contests are due almost entirely to losses by those firms in which incumbents use corporate resources to induce the dissidents to abandon their takeover attempt. These latter two findings suggest that acquisition-related benefits and costs are an important - although not necessarily the only - determinant of the stockholder wealth consequences of proxy contests.

Our most striking finding is that less than one-fifth of sample firms remain independent, publicly held corporations run by the same management team three years after the proxy contest. This finding reflects the facts that (i) proxy contests are typically followed by managerial resignations, even when dissidents fail to obtain a majority of board seats, and (ii) proxy contests are often followed by sale or liquidation of the target firm. In short, a dissident challenge poses a serious threat to incumbent managers. This evidence suggests that proxy contests serve as a forum through which public stockholders can initiate a referendum on major corporate policy shifts, as well as a means of inducing the management changes that are apparently necessary to implement such shifts.

\section{Appendix}

Case studies of 20 top management resignations within three years of a proxy contest in which dissidents did not obtain majority control of the board

This appendix contains brief case studies of resignations by top managers (defined as CEO, chairman, or president) for the 20 sample firms in which dissidents waged a proxy contest, but did not obtain a majority of board seats. Each case study describes the contest outcome and the circumstances surrounding the managerial resignation, including the position(s) of the officer(s) who resigned and any links to the dissident stockholders. Wall Street Journal (WSJ) articles are our primary information sources, but. we also rely on information published in proxy statements, annual reports, and forms $10-\mathrm{K}$. The final entry for each firm is the ciassincation of the managerial resignation (which underlies the aggregate data in panel B of table 7) and the length of time between contest outcome and the managerial resignation (which underlies the aggregate data in panel $\mathrm{A}$ of table 7).

American Bakeries Company The dissidents elected four of the 12 directors on the classified board. Of the remaining eight directors, four represented management and four were to be outside directors acceptable to both management and dissident directors. The dissident leader immediately replaced Robert E. Grant (age 56) as chairman of the executive committee (which was the title given the firm's CEO position). Mr. Grant, who had failed to be reelected to the board. resigned from the company effective five months hence. The WSJ report quotes Mr. Grant as 
saying he resigned 'because I had no other choice. I'd been the key ?erson in this company for several years, and I don't intend to be anything less than that'. By the iffective date of Mr. Grant's resignation, both the chairman of the board (L. Arthur Cushman, J:-, age 51) and the president (George F. Turci, age 51) had also resigned their posts, although both men remained directors. The dissident leader assumed the duties of both positions, and the WSJ report quotes him as saying that events since the election of his slate have 'been leading up to this [the two resignations]. I believe everyone wanted to end any possible strain and divisiveness in the company, and it was felt that this was the only way to do it'. Classification: Resignation and replacement by dissident within one year of contest outcome.

Canal Randolph Corporation The dissidents, led by Asher Edelman, settled with management in a compromise agreement that gave them three of the six board seats. The settlement came before the election was held and after the courts had ordered the company to reinstate cumulative voting, under which the dissidents' $28.7 \%$ stake would enable them to elect at least two of the six directors. Under the terms of the settlement, Mr. Edelman was named vice chairman of the board and chairman of the executive committee, while Sir Walter Salomon (age 76) was to continue as chairman and Raymond French (age 63) was to continue as president and CEO. Mr. Edelman emphasized to the WSJ that these titles were effective only until the compromise slate was approved by stockholders at the annual meeting, i.e., that the new board would reconsider these positions. He also expressed his interest in working with Mr. French, since the primary target of his campaign against incumbent management had been Sir Walter. Specifically, Mr. Edelman characterized Sir Walter as a '76-year-old chairman' who ran the company far too conservatively and ' $a$ foreign resident who spends little time in the U.S'. Sir Walter resigned unexpectedly from the position of chairman and from the executive committee at the annual meeting, while retaining his directorship. Immediately after the meeting, the new board named Mr. French to the additional post of chairman. Sir Walter's stated reason for his resignation was: 'It's time to entrust the future of the company to the younger generation'. The ccmpany was subsequently liquidated, as Mr. Edelman's platform had recommended. Classification: Resignation within one year of contest outcome amid visible signs of conflict with dissidents who now have board representation.

Chicago Rivet \& Machine Company Ralph W. Jindrich (age 54), president and CEO, resigned and was replaced by John A. Morrisey, chairman (age 45) two months after the dissidents obtained board representation. John Morrisey and his brother were major stockholders, with a combined $6.1 \%$ of the common stock. At the time of Mr. Jindrich's resignation, the dissidents had amassed a $10.6 \%$ stake and had obtained (via cumulative voting) one of the two board seats they sought, but hostilities between the incumbents and dissidents continued. The dissidents claimed that the board needed 'a new outlook' because of the firm's ongoing poor earnings performance, and Mr. Jindrich's resignation followed by three months the announcement of an annual loss. Four months after Mr. Jindrich's resignation, hostilities were effectively resolved when the company renurchased the dissidents' shares at a premium, negotiated a standstill agreement, and the one dissident director resigned. Classification: Resignation before contest outcome was resolved.

Chock Full O'Nuts Corporation The dissidents lost their initial proxy challenge, threatened a second contest, and acsepted greenmail before mounting the second challenge. One of the dissidents' major criticisms of incumbent management was that they weren't using the company's valuable real estate in New York City efficiently. In part, they blamed this shortcoming on the firm's 80-year-old founder and chairman, who died subsequently (during the hostilities). His successor attempted to remedy some of th. company's profitability problems by leasing the firm's restaurants to others and by developing the firm's (relatively high profit margin) business as a supplier of coffee to restaurants. In the process, the successor to the complany founder acquired Chase \& Sanborn and hired its president, Arthur R. Berman (age 45), as president and chief operating officer of Chock Full O'Nuts. Mr. Berman resigned to 'pursue other interests' two years iater and covild not be reached by the $W S J$ for comment on the reasons for his resignation. Classification: Resignation in third year following contest outcome at other than normal retirement age (age 45). 
Citadel Holding Corporation The company settled with the dissidents, naming their three representatives to an expanded ten-member board, when the dissidents continued to seek board representation after the company agreed to be acquired by another firm. The dissidents' original platform called for sale or merger of the company. Management had announced an agreement to be acquired by Great Western Financial Corp. the day before the scheduled stockholder meeting. at least partially in an attempt to delay the contested election. Following the merger announcement, the dissidents continued to seek board seats as 'protection for all shareholders' if completion of the sale was delayed or terminated. In response, management switched the term of the CEO, Spencer Scott (who was currently up for reelection to the classified board), with the term of another director who was not up for reelection, and named the three dissidents directors. The acquisition was supported by Mr. Scott and opposed by the dissident leader, Alfred Roven.

Two months after the settlement with the dissidents, the company terminated the acquisition agrecment when its investment banker refused to issue the type of fairness opinion called for by the agreement. At that time, Mr. Scott (age 63) resigned as chairman, CEO, and a director. He was to retain the title of chairman emeritus and serve as a consultant to the company. The WSJ report mentions Mr. Scott's difficulties with Mr. Roven, and quotes an unnamed executive as saying 'Scott was his own man [as chairman]. Barrone [his successor as CEO] is a harmonizer'. Six months after Scott's resignation, the company dismissed him from his consultant's position 'for cause'. The company refused to elaborate except to say it was disputing $\mathrm{Mr}$. Scott's claims for severance pay, and that it 'believes that it may have substantial counterclaims against Mr. Scott'. A special committee of the board was formed to investigate the company's past relationship with Mr. Scott, who could not be reached by the WSJ for comment. Classification: Resignation within one year of contest outcome amid visible signs of conflict with dissidents who now have board representation.

Condec Corporation The dissidents won seven seats on a 15-member board, running on a campaign to oust incumbent management and take the firm private. The dissident leader, William Farley, alleged that Condec management, led by Norman I. Schafler (age 66), was 'weak', 'confused', and had compiled a 'miserable track record' by running the company 'carelessly and without strategy'. Moreover, he said, Condec was not a 'Schafler family heirloom to be handed down from father to son' [Mr. Schafler's 33-year-old son was vice president-operations]. According to the WSJ report, the stockholder meeting was especially heated, with one stockholder saying that he intended to 'crack the whip' on management and demonstrating his intention by 'cracking a whip in the center aisle of the meeting room'. Within four months of the contest outcome, Mr. Schafier led a management group in a competing offer to take Condec private. Their offer was immediately topped by Mr. Farley. Upon acceptance of his offer, Mr. Farley was named chairman and CEO, succeeding Mr. Schafler. Mr. Schafler also sold the Schafler family stock in Condec to one of Mr. Farley's companies, resigned his directorship, and 'would have no further connection with the company'. Gerald Rosenberg, the company president, resigned simultaneously. Stockholders approved new management's buyout offer three months later. Classification: Resignation and replacement by dissident within one year of contest outcome.

Cook United Corporation The dissidents obtained three of the nine board seats they sought in the election, alleging tha the company's earnings performance had been a 'very sorry' one. The company's chairman and CEO, Martin M. Lewis (age 63), was criticized by the dissidents for his statement that 1978 was an 'especially gratifying year'. According to dissident proxy materials: 'It is difficult to understand how a $2 \%$ return on total assets and less than a $1 \%$ return on sales can be 'especially gratifying' to anyone with an interest in the company, let alone the chairman.' Cook continued to experience repeated losses after the proxy contest, and was forced to substitute stock dividends for the cash dividends it had begun paying during the election campaign. Three years after the contest outcome, Mr. Lewis resigned as CEO amid continued financial difficulties. He was replaced by the company president, George Jeffers (age 53), with Mr. Lewis continuing as chairman. According to Mr. Lewis, his resignation was part of 'the orderly transfer of the lines of authority begun four years ago'. The new CEO, Mr. Jeffers, resigned eight months later without explanation and was replaced by a temporary managenent committec that included a dissident director. The individual who replaced the committee resigned the CEO position 14 months after 
his appointment. Meanwhile, the company had filed for bankruptcy protection under Chapter 11 because its lenders would not extend additional credit. Classification: Resignation in third year following contest outcome amid other signs of dissident involvement.

Deltona Corporation The dissidents abandoned their efforts to unseat the board when management completed the sale of a $43 \%$ stake to Topeka Group Inc. in a 'friendly hands' stock placement during the dissidents' solicitation attempt. 'Three months later Frank E. Mackle, Jr. (age 69), the founder, chairman and CEO, and Frank E. Mackle III (age 41), president and chief operatin: officer, resigned from the company. The Mackle family retained ownership of $5.8 \%$ of the voting stock, and Mr. Mackle III expressed his intention to run for a directorship at the next annual meeting. He cited the 'friendly hands' stock placement and differences in styles of management [between a family-run company and one managed by outsiders] as the reasons why he and his father resigned. According to the WSJ report, Mr. Mackle III stated: 'There were some style differences [between the Mackles and Topeka management]. Things will be smoother' if the Mackles leave the company. Classification: Resignation and replacement by buyer in a 'friendly hands' stock placement within one year of contest outcome.

FGI Investors After two attempts by the dissident group to elect trustees, management issued a large block (400,000 shares) to U.S. Lend Lease Inc. The dissitents sued to stop the sale, alleging that management had engaged in 'corporate ballot stuffing' and had breached its fiduciary duty to stockholders by failing to submit the matter to a vote, and by selling shares at too low a price. The dissidents lost both their suit and the election, the latter by a narrow margin of 26,000 votes (they had unsuccessfully sought to block U.S. Lend Lease from voting its 400,000 shares). Three months later, amid continued litigation by both sides, the dissidents agreed to sell their shares to the company and U.S. Lend Lease and to settle all litigation. Three months later, Arno Krumbiegel (age 37), president and CEO of FGI, resigned to start his own consulting firm. He was immediately replaced by the president of U.S. Lend Lease, which at the time owned about $40 \%$ of FGI's stock. According to the WSJ report, the treasurer of FGI commented: 'With the advent of U.S. Lend Lease, and their eagerness to be active in the [trust's] management, Mr. Krumbiegel was willing to step aside'. Classification: Resignation and replacement by buyer in a 'friendly hands' stock placement within one year of contest outcome.

Kennecott Corporation After management had claimed victory in the contested board election and while the dissidents (Curtiss-Wright Corporation) were challenging that victory in the courts, Frank R. Milliken (age 65), chairman and CEO, announced he would retire effective almost immediately. [The U.S. Supreme Court ultimately affirmed a lower court ruling that a new election be held because Kennecott's proxy materials were false and misleading.] Mr. Milliken, who had been the subject of scathing personal attacks by the dissidents for alleged incompetence and mismanagement, had previously announced his iniention to postpone his retirement for another eleven months. Mr. Milliken was immediately replaced by Thomas D. Barrow (age 54), a senior vice president and director of Exxon Corporation. According to WSJ reports: 'Industry sources see the ... Kennecott decision to name a new CEO as a defensive move in the company's continuing proxy battle with Curtiss-Wright Corp. Kennecott insiders have been concerned with the company's ability to ward off another Curtiss-Wright challenge with two lame duck top executives [Mr. Milliken and William Wendel, age 64, the corspany president]'. In an interview, the new CEO cited the upcoming proxy fight with Curtiss-Wright as the 'major situation' facing him at this time. T. Roland Berner, the Curtiss-Wright chairman, commented: 'I'm talking about replacing the [Kennecott] board. This [the Barrow appointment] in no way vitiates the need to su'tstitute for that board. They're trying to duck oust, and we aren't going to let them'. Despite these remarks, Curtiss-Wright settled on a compromise slate with new Kennecott management two weeks later. Classification: Resignation before contest outcome was resolved.

The Louisiana Land \& Exploration Company This situation is similar to Kennecott's - although management claimed victory in the election, the dissidents' challenged this outcome in the courts, claiming a new election should be held because management had misrepresented the firm's financial performance during the campaign. The dissident leader was particularly concerned 
because two million of the estimated 30 million shares voted in the election originally voted for the dissidents, but later switched to management. The dissident leader claimed that if those votes hadn't changed, the dissidents would have won'. The Louisiana Land proxy fight is notable because the company had several large blockholders - Carl Lindner's American Financial Corp. with a recently purchased $5 \%$ stake, the Hunt family's Placid Oil with $12.4 \%$, Pioneer Corp. with 7.2\%, Amerada Hess with 5.3\%, and Boone Pickens' Mesa Petroleum with 1\%. While awaiting the outcome of the dissidents' lawsuit, management caused the company to repurchase the combined $17 \%$ stake held by the Hunt family and American Financial. The Hunts had voted their 12.4\% stake in favor of the dissidents, whereas American Financial had voted for management. Shortly after these repurchases, the firm was placed on Credit Watch (and eventually its bonds were downgraded).

During this period of continued uncertainty about the company's future direction, John G. Phillips (age 61) resigned as CEO. Mr. Phillips, who retained the titie of chairman, was expected to be replaced as CEO by the company president. Althuigh the WSJ report describes the management change as coming 'in the wake of a lawsuit broughi by a group of dissidents ... alleging that Louisiana Land's management misled shareholders aboui the company's financial position and other matters during a proxy fight', Mr. Phillips claimed the ciiange had 'nothing whatsoever to do with the proxy fight'. Fourteen months later, at age 62, Mr. Phillips a'so resigned as chairman. In the interim, the company repurchased Pioneer Corp.'s stake (Pioneer had vated for the dissidents), and the dissidents lost their case in the courts. Classification: Resignation within one year of contest outcome at other than normal retirement age (age 61).

LLC Corporation The dissidents, led by Harold Simmons, won six of the 15 board seats. Six months later, a dissident (the chief financial officer of Mr. Simmons' Contran Corporation) was elected chairman, succeeding Stephen M. Friedrich (age 50), who was to continue as president and CEO. Four months later, following continued losses, Mr. Friedrich was asked to resign all positions with the firm, including his di-ectorship. According to the WSJ report, Mr. Friedrich's resignation was requested because 'we've had several years of losses. A change was deemed [necessary] in order to turn the company around'. At this time, Harold Simmons was elected chairman and Mr. Friedrich's duties were assumed by an associate of Mr. Simmons. Classification: Resignation and replacement by dissident within one year of contest outcome.

Management Assistance Inc. The dissidents, led by Asher Edelman, won four of ten seats on the classified board. Within five months, Raymond P. Kurshan (age 60), chairman, president, and CEO, resigned from the company along with two directors. Mr. Edelman named one replacement director, giving the dissidents five of nine buard seats. The positions vacated by Mr. Kurshan were to remain unfilled because, at the dissidents' urging, the company was in the process of liquidation. Although Mr. Kurshan couldn't be reached for comment, the WSJ report quotes a company spokesman as saying that he believed Mr. Kurshan resigned because he thought it 'in the best interests of the company with all the divisiveness' as a result of the proxy contest and related lawsuits. Mr. Edelman had filed suit against Mr. Kurshan, asking compensatory, special, and punitive damages for Mr. Kurshan's allegedly libelous, false, misleading, and defamatory statements about Mr. Edelman during the proxy contest. This lawsuit was dismissed as part of the settlement agreement that accompanied Mr. Kurshan's resignation from the counpany. Classification: Resignation within one year of contest outcome amid visible signs of conflict with dissidents who now have board representation.

New Jersey Resources Corporation NUI Corporation, a competitor utility, made an unsolicited offer to purchase the company. After management rejected the offer, NUI announced that it would take its proposal directly to the stockholders through a proxy contest, which management claimed to win. However, NUI brought litigation challenging the fairness with which the election had been run and persuaded the courts to order a new election. Litigation between the two companies continued until New Jersey Resources agreed to a premium repurchase of its shares held by NUI, which then signed a standstill agreement. One year and four months later, the 76-year-old shairman retired and was succeeded by the firm's president and CEO. The WSJ report of the retirement makes no mention of the hostile takeover attempt by NU1. Cluss:ficution: Resignation in second y cai following contest outcome at other than normal retirement age (age 76). 
Pantry Pride, Inc. Grant C. Gentry (age 60), the firm's chairman and CEO, was the tatget of the dissidents' campaign. For example, one WSJ article about the proxy contest is titled 'Pantry Pride Chairman Gentry's Record, Personality Are Seen as Focus of Dispute'. The article quotes the dissident leader as saying that incurnbent management has 'no incentive to operate the company efficiently because they have no stock to speak of, with the exception of the cheap warrants Gentry got'. Although the campaign was especially heated, the dissidents obtained no board seats. Two months later, management agreed to issue sufficient shares to transfer effective control of the company to MacAndrews \& Forbes, a private firm. According to Mr. Gentiy, one reason for the stock issuance was to 'get a concentration of shares' in the hands of a singie party and thus prevent future proxy battles. When the issuance was announced, the company claimed that Mr. Gentry would continue to run Pantry Pride. Three months later, however, Mr. Gentry resigneci and was succeeded by Ronald 0 . Perelman, the CEO of MacAndrews \&ic Forbes. Classification: Resignation and replacement by buyer in 'friendly hands' stock placernent within one year of contest outcome.

Pullman, Inc. Samuel B. Casey (age 51), the firm's CEO and president, was the target of the dissidents' campaign. The dissidents, two former insiders, alleged that Mr. Casey had mismanaged the company and sought to have him fired. According to WSI reports, the dissidents 'are betting that evern if they can't unseat Mr. Casey by a proxy contest, the questions they are raising will stir up enough adverse publicity to force him out of office'. Even though management won the election by a wide margin, the annual meeting was heated, as the dissidents were joined by other dissatisfied stockholders whe questioned Mr. Casey 'about his perq:aisites and the company". Mr. Casey remarked at the meeting: 'I don't know when I've stood up to so much minutiae and trivia from so many people who dor't know business'. Six months later, Mr. Casey resigned as president and CEO, at age 51, and was named to the previously vacant position of chairman. Classification: Resignation within one year of contest outcome amid other signs of dissident involvement.

H. H. Robertson Company The dissidents, led by Canada's Beizberg family in conjunction with Guardian Industries, were enjoined from voting their shares because of antitrust conflicts with Guardian. The Belzbergs made a second attempt to elect di ectors (without the participation of Guardian) after Robertson omitted its quarterly dividend for the first time since 19:36. In the settlement that followed by three weeks a subsequent court ruling favorable to the Belzbergs, management agreed to place three Belzberg representatives on the board without a vote. The WSJ reports that analysts speculated the move could lead to a wholesale departure of top management. One analyst commented: 'They may not leave immediately, but maybe they will after they get their toes stepped on a few times by Hyman [Belzberg] and the brothers'. The Belzbergs (who held approximately $20 \%$ of the stock) were said to be especially anxious to influence management to increase company profitability because they had seen the mirket value of their investment drop by one-half since buying shares. Six months later, James L. Davis (age 59), president and CEO, took early retirement in a period of persistent losses and continued inability to resume the firm's regular quarterly dividend payments. Classification: Rssignation within one year of contest outcome amid other signs of dissident involvement.

Saxon Industries, Inc. Management settled with the dissidents the day before the scheduled stockholder meeting by agreeing to name two of their representatives to the 12 -member board. The meeting was postponed indefinitely. After the settlement, management began to implement some of the dissidents' suggestions for change, e.g., they divested some assets and instituted a cost-cutting program. Despite these measures, the conipany filed for bankruptcy protection under Chapter 11 within the year. The company immediately named a new president/CEO who was 'experienced in managennent under Chapter 11' to succeed Stanley Lurie (age 61). Mr. Lurie was elected chairman. Two months later, Mr. Lurie resigned a.s chairman and a director after massive accounting irregularities became apparent. The dissidents subsequently filed suit against Mr. Lurie and subordinate officers, charging that the defendants had falsified the company's books, thereby making false and misleading statements about the company's financial condition during the proxy contest. Federal prosecutors found that the financial statements management released during? the 
proxy contest had overstated the firm's inventory by some $\$ 53$ million. According to the WSJ: 'The company, which reported operating profit of $\$ 6.5$ million that year, would have had to take large losses... if the fictitious inventory had been discovered'. Mr. Lurie eventually pleaded guilty to conspiracy and fraud charges. Classification: Resignation in second year following contest outcome amid other signs of dissident involvement.

Texas International Company Although management apparently won the contested election, a federal judge ordered that a new election be held because both sides had violated federal proxy rules. Additionally, stockholders defeated management's proposed stock appreciation rights plan. which the dissidents had criticized as providing excessive compensation to the five top managers if the company were sold or liquidated. One month later, the dissidents settled their dispute with management and, in return for expense reimbursement, agreed to become passive investors and dispose of their shares. Two weeks iater, George Platt (age 57), who was one of the three management nominees up for reelection to the classified board, gave up the title of president to fellow incumbent Robert $C$. Gist, who was previously executive vice president. We did not treat this as a managerial resignation since Mr. Platt retained the title of chairman and chief executive officer and since he simultaneously assumed operating responsibility for the company's oil and gas subsidiary, whose current president had $\mathrm{r}$ signed. However, twenty-seven months later, Mr. Platt announced his resignation to take retirement at age 59. Classification: Resignation in third year following contest outcome at other than normal retirement age (age 59).

Tosco Corporation A preliminary vote count showed that the dissidents had won no board seats although they attracted $37 \%$ of the votes cast, more than three times their own stake. The dissident leader commented at the time that 'this is only one game in a World Series'. He had earlier vowed that, even if his slate was not elected, he would 'continue his efforts to gain control of Tosco and to oust Morton Winston', president and CEO. After the initial vote count was revealed, the dissident leader announced his intent to 'challenge every vote' in court. While doing so, he increased his stake and retained an investment bank to find a buyer for the company 'willing to acquire control through buying the [dissident] group's holdings'. Less than three months later, hostilities between management and the dissidents ended when management caused the corporation to repurchase the dissidents' shares at a premium, the dissidents signed a standstill agreement. and both sides dropped all litigation. Five months after the greenmail transaction, Mr. Winston (age 52) resigned as president and CEO and was named chairman, a postion in which 'he won't have any day-to-day management duties'. The management change was apparently required by the company's lenders as part of Tosio's debt renegotiations. Mr. Winston had been repeatedly questioned at the post-greenmail annual meeting about the firm's 'erratic performance', i.e., the wide swings in reported earnings. The WSJ suggests: 'Those wide swings created something of a credibility problem ior Mr. Winston, who in recent years has more than once had to revise overly optimistic earnings projections...' Classification: Resignation within one year of contest outcome at other than normal retirement age (age 52).

\section{References}

Alchian, Armen A. and Harold Demsetz, 1972, Production, information costs, and economic organization. American Econonic Keview 62, 77\%-795.

Asquith, Paul, Robert F. Bruner, and David W. Mullins. Jr., 1987, Merger recurns and the form of financing, Working paper (Harvard University, Cambridge, MA).

Borstadt, Lisa $F$. and Thomas J. Zwirlein, 1987. The role of proxy contests as a disciplinary mechanism: Jaternal labor market competition versus external capital market competition, Working paper (University of Colorado, Colorado Springs, CO).

Bradley, Michael, Anand Desai, and E. Han Kim, 1988. Synergistic gains from corporate acquisitions and their division between the sto kholders of target and acquiring firms. Journal of Financial Economics 21, 3-40.

Brows, Stephen \$. and Jerold B. Warner, 1985. U'sing daily stock returns: The case of event studies, Journal of Financial Economics 14, 331. 
Castanias, Rick and Herb Johnsoi, 1987. Proxy fight versus tender offer: The effect of dividend yield. Working paper (Univisity of California at Davis, Davis, CA).

Coughlan. Anne T. and Ronaid M. Schmidt, 1985, Executive compensation, management turnover. and firm performance: Air smpirical invesiigation, Journal of Accounting and Economics 7 . 43-66.

Dann, Larry Y. and Harry DeAngelo, 1989. Corporate financial policy and corporate control: A study of defensive adjustments in asset and ownership structure, Journal of Financial Economics 20, 87-127.

DeAngelo, Linda Elizabeth, 1988, Managerial competition, information costs, and corporate governance: The use of accounting performance measures in proxy contests, Journal of Accounting and Economics 10, 3-36.

Dodd, Peter, 1980, Merger proposals, management discretion and stockhclder wealth, Journal of Financial Economics 8, 105-138.

Dodd, Peter and Jerold B. Warner, 1983, Gn corporate governance: A study of proxy contests, Journal of Financial Economics 11, 401-438.

Gilson. Stuart C., 1988, Management-borne costs of financial distress. Unpublished Ph.D. dissertation (University of Rochester, Rochesier. NY).

Klein, April and James Rosenfeld, 1988, Targeted share repurchases and top management changes, Journal of Financial Economics 20, 493-506.

Manne. Henry G., 1965. Mergers and the market for corporate control. Journal of Political Economy $73,110-120$.

Patell, James M., 1976, Corporate forecasts of earnings per share and stock price behavior: Empirical tests, Journal of Accounting Research 14, 246-2i6.

Pound, John, 1988, The efficiency of shareholder voting: Evidence from proxy contests. Journal of Financial Economics 20, 237-265.

Walsh, James P., 1988, Top management turnover foliowing mergers and acquisitions, Strategic Management Journal 9, 173-183.

Warner, Jerold B., Ross L. Watts, and Karen H. Wruck, 1988, Stock prices and top management changes, Journal of Financial Economics 20, 461-492.

Weisbach, Michael S., 1988. Outside directors and CEO turnover, Journal of Financial Economics $20,431-460$. 